\title{
Citizenship and the Indonesian Diaspora: Lessons from the South Korean and Indian Experiences
}

Susi Dwi Harijanti ${ }^{\S}$

Bilal Dewansyah ${ }^{*}$

Ali Abdurahman ${ }^{\alpha}$

Wicaksana Dramanda ${ }^{ \pm}$

\begin{abstract}
The existence and movement of diasporas across the world significantly challenge the existing legal norms on citizenship and migration. The responses from law-makers from the origin countries vary. Most European, Latin America and African countries adopt dual citizenship laws. However, most countries in Asia-Pacific region, including Indonesia, do not favour dual citizenship. This is mostly because of the ideological perception of citizenship. In this sense, many countries grant special status or schemes to their diaspora (neither citizens nor residents of the country) in the form of an external quasi-citizenship based on ethnic descent, called "ethnizenship" by Bauböck.This article, drawing on on-going research, compares the Indonesian experience with that of two other countries that have adopted quasicitizenship schemes. India and South Korea have been chosen for comparison since both countries have particular statutes that recognise and regulate diaspora status. India created the Person of Indian Origin (PIO) card scheme in 1998 and Overseas Citizens of India (OCI) card scheme in 2003. These two schemes merged in 2015 into the Overseas Citizens of India Card Holder (OCC) scheme through the Citizenship (Amendment) Act 2015. While India adopts a regulatory model of diaspora through a citizenship law regime, the South Korean experience showsa different attitude towards their diaspora. The Korean Government has refused the Korean diaspora's proposal for dual citizenship and created a semicitizenship called "Overseas Korean" status through immigration law. This article discusses the Indian and South Korean experiences dealing with their diaspora in order to propose a regulatory model for Indonesia's diaspora.
\end{abstract}

Keywords: Indonesia; South Korea; India; dual citizenship; diasporas; quasi-citizenship.

\section{Introduction}

Diasporas across the world have challenged the existing legal norms on citizenship and migration. The responses from law-makers from the countries of origin vary.

${ }^{\S}$ Professor of Constitutional Law, Faculty of Law, Universitas Padjadjaran (UNPAD), Indonesia.

Email: susi.dwi.harijanti@unpad.ac.id

${ }^{¥}$ Lecturer on Constitutional Law, Faculty of Law, Universitas Padjadjaran (UNPAD), Indonesia.

Email:b.dewansyah@unpad.ac.id

a Senior Lecturer on Constitutional Law, Faculty of Law, Universitas Padjadjaran (UNPAD), Indonesia. Email: abdurahman@unpad.ac.id.

${ }^{ \pm}$Researcher at Pusat Studi Kebijakan Negara (PSKN)/ Centre for State Policies Studies, Faculty of Law, Universitas Padjadjaran (UNPAD), Indonesia.

Acknowledgement: This paper is based on on-going socio-legal research entitled "Model Pengaturan Diaspora Dalam Rezim Hukum Kewarganegaraan dan Keimigrasian Indonesia" (The Regulatory Model for the Indonesian Diaspora in Citizenship and Immigration Law Regimes) funded by Universitas Padjadjaran (UNPAD). This article is an expanded version of a paper presented at the Migration Conference 2017, Harokopio University, Athens, 23-26 August 2017.esearcher at Pusat Studi Kebijakan Negara (PSKN)/ Centre for State Policies Studies, Faculty of Law, Universitas Padjadjaran (UNPAD), Indonesia. Email: wicaksanadramanda@live.com. 
Many European, Latin Americas and African countries have adopted dual citizenship laws for various reasons, including immigrant integration, maintenance of loyalty to the country of origin or ethnic ties (Dewansyah, 2016). However, most countries in the Asia-Pacific region which gained their independence through a decolonisation process do not favour dual citizenship, including Indonesia, mostly because of the ideological perception of citizenship (Hassall, 1999, p.49). In this sense, many countries grant special statuses or create schemes for their diasporas (neither citizens nor residents of the country), leading to an external quasicitizenship status based on ethnic descentcoined by Bauböck as "ethnizenship" (Bauböck, 2007, p.2396).

In the case of Indonesia, while the rejection of the dual citizenship proposal is obvious (Harijanti, 2016), the adoption of an ethnizenship status as an alternative regulatory model is plausible. For instance, former President of the Indonesia Diaspora Network (IDN), a global network of the Indonesian diaspora, Al Arief recommends such a regulatory alternative to Indian diaspora status which is formally not dual citizenship (Dewansyah, 2016, p.7). Similarly, Iman Santoso, Indonesian immigration law professor, suggests giving a Person of Indonesia Descendant's Card (Kartu Keturunan Orang Indonesia) to ex-Indonesian citizens and their descendants that can be used to have exemption from visa requirements and entitle the bearer to some legal rights, apart from political participation rights (Santoso, 2014, p.118). However, the discourse is not merely academic, because it has political relevance in the context of the Citizenship Law amendment plan as stated in the National Legislation Plan 2014-2015.

In order to seek a suitable and realistic regulatory scheme for the Indonesian diaspora, this article compares experiences from two countries which have adopted quasi-citizenship for their descendants overseas; that is, India and South Korea. India created the Person of Indian Origin (PIO) card scheme in 1998 and the Overseas Citizens of India (OCI) card scheme in 2003 (Naujoks, 2015, pp.21-24). These two schemes merged in 2015 into the Overseas Citizens of India Card Holder (OCC) scheme through the Citizenship (Amendment) Act 2015 (Section 7A). The new scheme gives benefits to the Indian diaspora not only in the form of visa exemptionsfor visiting and staying in India, but also by guaranteeing some legal rights with the exception of political participation rights (Xavier, 2011, p.46). While India adopts a regulatory model of diaspora through the citizenship law regime, South Korea's experience shows a different attitude towards their diaspora. The Korean Government has refused the demand of the Korean diaspora in North America for dual citizenship, and consequently it created a semi-citizenship called "Overseas Korean" status through the immigration law regime as regulated in the Act on the Immigration and Legal Status of Overseas Koreans (the Overseas Koreans Act/OKA) in 1999 with F-4 visa scheme with its amendment in 2004 which includes the Korean-Chinese diaspora (Lee, 2012a, pp.93-94). This law gives benefits for the Korean diaspora in the form of important rights such as freedom of employment and economic activity, and national treatment with regard to real property rights and transactions, foreign exchange transactions, and health insurance and pensions (Lee, 2003, p.109). 
India and South Korea have been chosen as comparisons not only because they have laws that recognise and regulate diaspora status and face an almost similar problem with dual citizenship proposal, but they have also been considered as two countries at a similar stage of development to Indonesia as postcolonial Asian states that gained independence at a similar time. This paper will use the results from this comparison as a benchmark to develop a regulatory model for the Indonesian diaspora.

This paper is structured as follows. Following the introduction, we outline the emergence and latest developments of the Indonesian diaspora. Then, we provide a comparison with India and South Korea, followed by discussions concerning the potential model to deal with the Indonesian diaspora.

\section{The Indonesian Diaspora: Emergence and Current Development}

The first step in discussing the Indonesian diaspora is to define the meaning of diaspora. "Diaspora" mostly refers to the community who live abroad but still maintain relations with their homeland. These relations includesocial, economicand emotional ties to their home country. Ember et al. (2005, p.xxvi) clearly define diaspora:

A people dispersed by whatever cause to more than one location. The people dispersed to different lands may harbour thought of return, may not fully assimilate to their host countries, and may maintain relationships with other communities in the diaspora.

Another definition of diaspora has proposed by Brubaker (2015, p.1), who relates it to the context of human migration. It refers to a group of migrants who maintain emotional and social ties with a homeland. Moreover, Brubaker highlights three general criteria to define diaspora: dispersal, homeland orientation, and boundarymaintenance. Butler generally defines a diaspora as "dispersion of a people from its original homeland" (Muhidin and Utomo, 2015, p.4). Based on those definitions, one may consider the Indonesian diaspora to consist of Indonesians by birth and ancestry who live outside Indonesia, or in many cases it refers to "overseas Indonesians" (Muhidin and Utomo, 2015, p.4).

In the past, the term "diaspora" was related to the forced migration of the Jewish population from their homeland. However, in recent decades, it has become a universal phenomenon and the term has replaced many types of human migration, including labour migrants, refugees and marriage migrants. The reason for this change is because current migration is voluntary rather than involuntarily, such as displaced populations or slavery (Muhidin and Utomo, 2015, p.95).

Indonesia is no exception. During the last three decades, Indonesia has witnessed fundamental changes in many aspects, including its political outlook and demographic characteristics. The Indonesian population is now more educated, has relatively adequate economic capacities, and has higher life expectancy. These factors allow them to travel around the world for different reasons, including earning money, continuing education or even living abroad. As a result, mobility 
patterns among Indonesians have also changed. In terms of international migration, Indonesians have been migratingfor a long time: for instance, there is a study that shows that in the early 1900s people from the Sangir-Talaud of northeastern Sulawesi migrated to Mindanao (Tan-Cullamar, 1993, p.40). However, a more extensive scale of international migration only began to take place in recent decades. This has ledthe number of Indonesian people who live abroad to riseover time, returning significant remittances. In 2017, the Minister of Foreign Affairs estimated that around 4.3 million Indonesian citizens were living abroad (Basnur, 2017) constituting almost 2 per cent of the total Indonesian population. Most members of the Indonesian diaspora live in Malaysia. In terms of remittances, according to the Migration and Remittances Fact-book 2016, Indonesia received USD 10.5 billion (World Bank Group, 2016, p.24). This placed Indonesia in the top 10 developing countries and top 14 countries in the world with high levels of remittance receipts in 2015.

However, it should be noted that data on the number of the Indonesian diaspora varies, depending on the definition and data source (Muhidin and Utomo, 2015 , p.5). For example, in January 2013, Dino Patti Djalal estimated the Indonesian diaspora to number 4,700,000. He provided the number from 167 Indonesian Diplomatic Offices overseas, but in June 2013 he gave a number that had increased to $6,000,000$. For the latter number, the data source was Republika Newspaper, which is circulated at the national level.

Unlike other countries in Asia, such as China, India and South Korea, awareness of the Indonesian diaspora began as late as in 2012. The first Indonesian diaspora congress was held in Los Angeles on July 7, 2012, initiated by Indonesian diaspora members in the US and Dino Patti Djalal, the Indonesian Ambassador to the US at the time. The first congress also marked the establishment of the Indonesian Diaspora Network (IDN), which aims to facilitate the needs of the Indonesian diaspora and communicate these needs to the Indonesian Government. Since then, there has been a growing interest in the Indonesian diaspora. The IDN itself has initiated task force groups which aim to provide advocacy, among other services. The task forces include: Immigrant and Citizenship, Migrant Workers, Liveable Cities, Aerospace, Culinary Heritage and Culture Promotion, Education and Human Resources Development, Government Cooperation and Good Governance and finally, Science and Technology.

The second congress was held in Jakarta in August 2013 and had a theme of "Pulang Kampung" which literally means"Coming Home". With the theme of "Diaspora Bakti Bangsa" (Diaspora Devotion to the Nation), the third Congress also took place in Jakarta, in 2015. The Congress discussed a variety of issues, including sustainable cities, with Jakarta and Bandung as study cases, healthcare, learning education, the creative economy, maritime development and dual nationality.

The fourth and most recent congress took place again in Jakarta in July and August 2017 under the theme of "Bersinergi Bangun Negeri" (Together We Build the Nation). President Barack Obama gave a speech at this event, as he is regarded as a "special friend of Indonesia" given the fact that he spent some of his early childhood in Jakarta. The speakers included Sri Mulyani (Minister of Finance), 
AniesBaswedan (Governor of Jakarta), and Ridwan Kamil (Mayor of the City of Bandung). Participants at the congress gathered to discuss economic and social culture issues with the aim of improving the lives of Indonesians at home and abroad.

As mentioned above, one of the fundamental issues raised by the Indonesian diaspora is dual nationality, as launched at the third congress, and this is proposed by Indonesian people who still hold Indonesian citizenship as well as those who have already become foreigners. Mostly, overseas Indonesians are of the opinion that their existing presence abroad gives benefits for Indonesia in terms of remittance, transfer of technology and investment. In addition, being an Indonesian citizen will allow them to maintain direct relations not only with their families but also with their community in Indonesia. In short, they are keen to maintain objective as well as emotional ties. Indeed, this is one characteristic of diasporasaround the world.

As will be discussed later, the Indonesian legal policy on citizenship does not allow full dual nationality. Thus, the question remains: how does one accommodate the Indonesian diaspora's aspiration in this regard?

In 2015, an initiative to amend the existing 2006 Acton Indonesian Citizenship was proposed by Commission III of the House of Representatives. A number of issues provided the driving force behind the proposed amendment. First and foremost was the possibilityof allowing full dual citizenship and addressing the weaknesses of the citizenship regime under the 2006 Act, including a disharmony in the rules between the 2006 Act and its implementing regulation. The need to solve this disharmony is fundamentally important, but the adoption of dual citizenship is considered a more controversial issue (Harijanti, 2017).

Rather than amending the existing Act onIndonesian Citizenship, more recently, the Indonesian Government has issued Peraturan Presiden (Presidential Regulation, hereafter PR) No. 76 of 2017 concerning "Fasilitas Masyarakat Indonesia di LuarNegeri" (Facility for Overseas Indonesians Community) as an attempt to accommodate the needs of the Indonesian diaspora. The regulation came into force on August 3, 2017. The major reason behind the issuance of this regulation is to empower and to increase the role and contribution of overseas Indonesians in the field of development, so that they can actively play a role in economic, social and cultural activities.

Interestingly, the new Presidential Regulation (PR) No. 76 of 2017 seems to provide wider definitions of the Overseas Indonesian Community. It does not only recognise former Indonesian citizens and children of former Indonesian citizens, but also it includes foreigners whose parents are Indonesian citizens staying and/or working outside Indonesia.

This new Regulation also introduced the "Kartu Masyarakat Indonesia di Luar Negeri" (KMILN), known as the Overseas Indonesian Community Card. The Indonesian Government will issue this Card to those who meet certain criteria and requirements with the emphasis that the applicants do not have legal problems with the Indonesian Government. The Ministry of Foreign Affairs is in charge of issuing the Card for a certain period of time. However, the regulation fails to 
provide in detail in relation the criteria, requirements and exact period of time and it delegates producing detailed rules to Peraturan Menteri Luar Negeri or the Minister of Foreign Affairs Regulation (hereafter the MoFA Regulation) In other words, the PR delegates certain subject matter to the MoFA Regulation.

The facilities offered by Article 3 (2) of the regulation include: opening a public bank account; owning property; and establishing a business entity. However, Article 3 (1) of the PR states that facilities may be given to the holder of a KMILN. This means that these facilities do not automatically apply to the card holder. Thus, there is discretion on whether to give those facilities. From a legal point of view, this kind of norm would create uncertainty. In short, the regulation lacks legal certainty. If there is a requirement to hold a Kartu Tanda Pengenal or personal identity card or Kartu Keluarga (Family Card) for these facilities, a KMILN holder can use it to meet the requirement.

The issuance of PR No. 76 of 2017 is presumably not adequate to tackle the Indonesian diaspora problem. To find an appropriate model for the Indonesian diaspora, it is necessary to explore other countries with similar conditions to Indonesia. The following section will compare the Indonesian with the Indian and South Korean diasporas.

\section{Diaspora Setting Models in India and South Korea: A Comparison}

In general, the presence of Indian and South Korean diasporas is based on the phenomenon of immigrant workers (Sahai, 2013, p.51). The magnitude of the diaspora communities from both countries has result in a need for a formal policy governing the diaspora in each country that aims to develop and build relationships with the diaspora communities. The Indian diaspora policy was created by changing the citizenship law in which the Government of India allowed dual citizenship (Xavier, 2011, p.45). Sadly, the fully-dual citizenship proposal failed because of three main obstacles: constitutional provisions that ban dual citizenship; legislative trends that harden such processes; and security considerations (Xavier, 2011, pp.43,45).

This Indian policy is different from that of South Korea which regulates its diaspora policies through immigration laws. One of the reasons why the Indian Government makes use of the citizenship laws is the perception that the immigration laws are merely instruments to provide protection in the context of outflows entering the territory of the state. Moreover, the diaspora policy does not merely deal with immigration protection, but rather is about the "management" of the diaspora (Sahai, 2013, p.52). In the case of South Korea, the development of a diaspora policy under the immigration laws is based on an ethnizenship concept which is broader than the concept of citizenship. Thus, through the concept of ethnizenship, the Korean Government needs to maintain relationships with ethnic Koreans who have obtained citizenship status from other countries before the Republic of Korea was established that cannot be resolved by modern citizenship approach (Lee, 2012a, p.86). In addition, the South Korean Government is of the opinion that using the immigration law regime will have less effect on diplomatic 
relations between South Korea and the countries where the Korean diaspora are now settled, such as China (Yoon, 2007, p.95).

The regulation of the diaspora in India was first done through the amendment of the citizenship law in 1999 under the Person of Indian Origin (PIO) scheme, which regulated three categories of the Indian diaspora: 1) former Indian citizens; 2) Descendants of Indian citizen to the third generation; and 3) spouses of those belonging to categories 1 ) and 2). This PIO Card was valid for 15 years and could be extended. Nevertheless, former Indian citizens who were citizens of Pakistan, Bangladesh, Afghanistan, China, Iran, Bhutan, Sri Lanka, and Nepal were excluded from the Indian diaspora. In the same year, South Korea also issued a diaspora regulation through the Act on the Immigration and Legal Status of Overseas Koreans, known as the Overseas Koreans Act (Lee, 2012a, p.93). Based on the Overseas Koreans Act, those who could be categorised as diaspora were former citizens of Korea and their descendants to the second generation. The meaning of "former citizens of Korea"is that those who are recognised as part of the Korean diaspora are those who have formally held the status of Korean citizen, namely ethnic Koreans who migrated before the government of the Republic of Korea was established in 1948 were not recognised as diaspora members (Lee, 2012a, p.93). Therefore, ethnic Koreans residing in the territory of China and some former Soviet Union countries are not recognised as part of the diaspora because they migrated before the Republic of Korea was established (Lee, 2012a, p.93).

Based on the above categorisation, both India and South Korea perceive a diaspora member as an ex-citizen, including their descendants to some extent. From these limitations, it appears that India has a looser restriction ongranting diaspora status until the third generation. The difference in these restrictions happens to occur because the diaspora phenomenon in India is older than that in South Korea. The spreading or migration of Indian society began a century and a half ago and has reached five to six generations (Kumar, 2015, p.1), so India has formed a looser policy so that more descendants of former Indian citizens can get diaspora status. The South Korean community's dispersion or migration only began in 1860 (Yoon, 2007, p.viii). In addition to differences in the diaspora category, the diaspora policy in South Korea does not include the spouses of its former citizens in the diaspora category.

The diaspora policies in India and South Korea have changed over time. In India, diaspora policy changes occurred in 2003-2015. In 2003 and 2005, the Government of India issued another diaspora policy model in addition to the PIO model; the model called Overseas Citizen of India ( $\mathrm{OCI}$ ). The $\mathrm{OCI}$ scheme clarifies the diaspora categories that can be given $\mathrm{OCl}$ cards as follows: someone 1) who was a citizen of India at the time of, or at any time after the commencement of the Constitution i.e. January 26, 1950; 2) who was eligible to become a citizen of India on January $26,1950 ; 3)$ who belonged to a territory that became part of India after August 15, 1947 ; 4) who is a child or a grand child or a great grand child of such a citizen; 5 ) who is a minor child of a person mentioned in points 1) untill 4); 6) who is a minor child and whose both parents are citizens of India or one of the parents is a citizen of India; 7) who is the spouse of foreign origin of an Overseas Citizen of India Card 
holder registered under section 7A of the Citizenship Act, 1955 and whose marriage has been registered and subsisted for a continuous period of not less than two years Immediately preceding the presentation of the application. The latest amendment took place in 2015, resulting in a new diaspora policy under the Overseas Citizen of India Cardholder (OCC) scheme that merged the PIO with the $\mathrm{OCI}$. Under this policy a Diaspora Indian who has held the PIO card is deemed as an OCC (Section 7A para. (2) of the Citizenship (Amendment) Act 2015).

Meanwhile, the diaspora policy change in South Korea resulted from a constitutional complaint filed by Korean Chinese (ethnic Koreans who are Chinese citizens) who are not categorised as part of the diaspora under the Overseas Koreans Act. In 2001, the South Korean Constitutional Court granted the complaint and forced the South Korean Government to amend the Overseas Koreans Act in 2004. The amendment includes ethnic Koreans originally excluded under the Overseas Koreans Act of 1999 as members of the diaspora (Lee, 2012a, p.5).

The granting of diaspora status is always followed by the granting of certain rights. For example, those registered as Indian diaspora members in the OCC scheme may freely exit and enter India (multiple entry life-long visa). OcC holders are also granted other rights in the form of financial, educational and economic rights, except in matters relating to the acquisition of agricultural/plantation properties, and some political rights in the form of the right to fulfil public positions. Meanwhile, granting certain rights to the diaspora in South Korea is done in a more complex way. Because South Korea's diaspora policy is built within immigration law regimes, the granting of certain rights to the diaspora is based on the type of visa that can be obtained by diaspora members.

The visas that can be obtained by South Korean diaspora members are F-4 and $\mathrm{H}-2$ visas. Both are basically a special visa to get a job in South Korea without going through the employment permit system as foreigners of non-Korean origin who are to be employed in South Korea. A diaspora member holding an F-4 visa has the rights attached to it in the form of the right to stay, the right to work, the right to freedom of financial transactions, the right to land and property ownership and the right to health insurance (Lee, 2012b, p.5). The F-4 visa is valid for three years and can be continually renewed. The F-4 visa is intended for diaspora members who wish to work in a field of work requiring certain expertise. Thus, low-skilled job sectors are prohibited for holders of this type of visa. The impact is that ethnic Koreans originating from China and ex-Soviet Union countries, who are generally low-skilled workers, cannot obtain this type of visa. Therefore, South Korean diaspora members with low expertise can obtain $\mathrm{H}-2$ visas intended for low-skilled job sectors. Although the work sector is differentiated, holders of $\mathrm{H}-2$ visas still get the same rights as F-4 visa holders (Lee, 2012b, p.5). The H-2 visa cannot last for more than five years.

Based on the diaspora regulatory model in India and South Korea, it appears that the context of the South Korean diaspora's need to return to their home country is a factor in their economic needs for better livelihoods in South Korea as that country's economy improves. In contrast, the Indian diaspora policy context is intended to capture the contribution of the Indian diaspora to the interests of 
Indian development, for example through remittances. World Bank data show that remittances received by India in 1991 reached \$2.1 billion and continued to increase to \$27 billion in 2007 (Dubey, 2013, p.77).

\section{Lesson Learnt from India and South Korea: Potential Regulatory Model for the Indonesian Diaspora}

Through a regulatory model optic, the initial idea of the incorporation of Indonesia's diaspora status has similarities with India's model, that is, to accommodate the status of dual citizenship for Indonesian citizens or former Indonesian citizens and their descendants. In Indonesia, this proposal became the major substance advocated in the on-process amendment plan of Act No. 12 of 2006 on Citizenship. Interestingly this amendment planning was stated clearly in Program Legislasi Nasional (National Legislation Programme) 2015-2019, the national legislative planning as initiated by the House of Representatives.

From a legal aspect Indonesia does not have a constitutional issue to apply dual citizenship, compared with that of India. In the case of India, constitutional amendment took place in order to allow full dual citizenship. In addition to the constitutional problem, the main barriers to adopting dual citizenship in Indonesia are mainly because the amendment to Act No. 12 of 2006 includes the issue of legislative trends and non-legal aspects. From the aspect of citizenship law development, the principle of single citizenship has been institutionalised in Indonesian citizenship legislation from independence (Act No. 3 of 1946) to the present legislation. So, the principle of single citizenship is inseparable from the understanding of Indonesian nationalism as a postcolonial country, similar to India and South Korea. In addition, Indonesia experienced problems in the past related to dual citizenship with the People's Republic of China (PRC) which applied the dual principles of citizenship to Chinese descendants in Indonesia. In that case, the Indonesian Government perceived dual citizenship to be ended primarily for reasons of loyalty and allegiance (Harijanti, 2017, p.7).

In the current context, although the application for dual citizenship is fully supported by the IDN and some NGOs, the government and several members of the House of Representatives are reluctant to accommodate the idea, and more favour a"softer" approach in the sense that full dual nationality is not the only solution to accommodate the Indonesian diaspora (Harijanti, 2017, p.18), for nationalism reasons (Dewansyah, 2016, p.10). This reflects the idea that Indonesian citizenship is still seen as an "ideological construction of politics and history" (Harijanti, 2017, p.19).

However, as mentioned above, there has been significant development in terms of subject matter that appears to have been influenced by $\mathrm{OCl} / \mathrm{OCC}$ practices in India. As mentioned previously, the Government of Indonesia introduced the Diaspora Card in 2017 (Budiari, 2017). The formal name of this card is Kartu Masyarakat Indonesia di Luar Negeri (KMILN) or Indonesian Overseas Community Card, regulated in Peraturan Presiden (Presidential Regulation, PR) No. 76 of 2017 on Facilities for Indonesian Overseas. Nevertheless, this card has no legal 
implications yet for Indonesian diaspora members that have already relinquished their Indonesian citizenship status and their families. The new regulation mostly gives benefits to overseas Indonesian citizens, who are mostly Indonesian migrant workers. This is evident based on Article 3 (2) PR No. 76 of 2017, which clearly states:

The facilities given for KMILN holders who are Indonesian Citizens, are:

a. open a public bank account;

b. own properties in Indonesia; and/or

c. establish an Indonesian business entity according to the provisions of legislation.

Meanwhile, for KMILN holders who are foreigners, this regulation only states that the, "... can be given facilities and easiness, according to the provisions of legislation" (Article 2 (3)). As a matter of interpretation, it can be concluded that foreigners who were Indonesian citizens and/or their family cannot enjoy the facilities guaranteed in Article 2 (2). Then, the kind of "facilities and easiness, according with the provisions of legislation" that are already given or will be given to foreigners who hold KMILNs are still questionable.

As a matter of fact, however, the current legal arrangements on the Indonesian diaspora can be understood since presidential regulation - as a lower-rank delegated legislation according to the Indonesian legislation system - cannot amend many laws that limit foreigners' rights in Indonesia. An example of this is Act No.5 of 1960 on Basic Agrarian Law which clearly prohibits foreigners from having ownership titles to land.

Apparently, the development of a diaspora card programme to be a more regulatory based diaspora status will be done in a way that is beyond the amendment of citizenship law as well as India's OCC regime regulated in citizenship law amendments, since it regulated in executive regulation (PR No. 76 of 2017 and has legal effect for former Indonesian citizens and their children. In addition, the incorporation of diaspora status and rights in India through the amendment of citizenship law is also criticised, because although the $\mathrm{OCI}$ (or OCC currently) is intended to recognise dual citizenship, the result is the reverse, not citizenship (Xavier, 2011, p.45). This means that amending citizenship law becomes ambiguous if it is to be regulated not as a citizenship status or recognition of dual citizenship, but as a special status for the Indonesian diaspora that is not citizenship.

In addition, the political setting in India when adopting the $\mathrm{OCl}$ was different from Indonesia's current political regime. In India, the idea of dual citizenship came from the government to draw the diaspora's economic potential to India, but the Parliament did not agree upon the amendment to citizenship laws, primarily referring to national security (Naujoks, 2015, pp.27, 29). Meanwhile, in Indonesia, the idea of dual citizenship has emerged from the aspirations of the people, especially the Indonesian diaspora. Sadly, serious efforts from the Government and the House of Representative have not yet been clear until now. In the near future, it is very likely that the adoption of full dual nationality through the amendment of the existing citizenship law would be rejected. 
The Indonesian Government is likely to adopt a pragmatic way of dealing with the Indonesian diaspora. It seems that the regulatory model to be pursued by the Government of Indonesia is more like the way South Korea organises overseas Koreans through the immigration law regime as reflected by the Diaspora Card programme and the extension of multiple entry visit visas only for the Indonesian citizen and their family based on Government Regulation (GR) 26 of 2016 (amendment of GR No. 31 of 2013 regarding Implementing Regulation of Law No. 6 of 2011 regarding Immigration).

In contrast to the Overseas Koreans Act, which also recognises a number of the Korean diaspora's legal rights, the current policy of the Indonesian Government is still limited to providing a small range of immigration privileges for diaspora members, without special legal rights. However, in relation to the rights of the Korean diaspora, Lee (2017) criticises the South Korean Government's policy that in his opinion is "too much concerned with the diaspora," for example, affirming the right to health insurance that can be obtained by anyone. This means that the fundamental needs of the Indonesian diaspora should be a major consideration, while still providing comprehensive consideration for certain sensitive legal rights. For example, although diaspora members' ownership of land and property in South Korea is not a problem, the idea of granting land rights with ownership title (hak milik) to the Indonesian diaspora should be considered carefully or even excluded.

Reflecting on the experience of South Korea, they set the status and rights of the diaspora in immigration law regime, not in executive regulation, but with an act of legislature (the Overseas Koreans Act). However, South Korea's choice to form a separate law for the diaspora is not a substantive issue, as this is the legislation tradition in South Korea when faced with new requirements (Lee, 2017). Meanwhile, for Indonesia whose politics of immigration law since 1992 have been intended to unify various immigration laws, arrangements for the Indonesian diaspora should be made by amending Law No. 6 of 2011 on Immigration.

Moreover, based on the experiences of India and South Korea, Indonesia needs to rethink the categories of diaspora members that should be legally regulated. Currently, the diaspora category is, mainly based on the opinion of Dino Patti Djalal, one of IDN's founders, too broad, because it covers not only Indonesian citizens and their descendants, but also Indonesian citizens abroad and foreigners who "love" Indonesia (Dewansyah, 2017, p.8). It is difficult to develop criteria according to Djalal's category (Santoso, 2014, p.118). In contrast, India and South Korea have made clear definitionsof their diasporas as groups of former citizens and their descendants to a number of generations who live outside their native country. In addition, India and South Korea also distinguish non-resident or overseas citizens from the diaspora category because this category of diaspora still holds citizenship status from their countries.. Indonesia also has no special need to grant certain statuses to Indonesian citizens abroad.

Indonesia's current regulation does not use the term "diaspora, which is stated expressis verbis.However, there are two approaches to defining the category of diaspora: a narrower sense and a broader meaning. The narrow category of the Indonesian diaspora, which also adopted by India and South Korea, can be seenin 
Article 136 (5) GR No. 26 of 2016 (see also Note of Explanation of this Article), which recognises three diaspora categories: the former Indonesian citizen, their spouse) and their children. Nonetheless, the broader approach seemingly adopted by PR No.76 of 2017, as discussed previously, uses "Indonesian Overseas Community" to cover both overseas Indonesian citizens and certain categories of foreigner (see Article 1 Point 1). But, if the foreigner categories in PR No.76 of 2017 can be perceived as the narrower concept of the Indonesian diaspora, it is indeed inconsistent with the categories adopted in GR No. 26 of 2016. In PR No.76 of 2017 Article 1 Point 2, "Foreigner" refers to non-citizens of Indonesia made up of:

1. former Indonesian citizens;

2. children who have relinquished their Indonesian citizenship status (in the case of a dual citizenship child which is allowed until they reach $18-21$ years old);

3. a foreigner whose parent is an Indonesian Citizen that has settled and/or works overseas.

The latter regulation does not cover the spouses and children of former Indonesian citizens as Indonesian diaspora members which were already recognised in the earlier regulation (GR No. 26 of 2016). But, interestingly, the latter adds a new category of Indonesian diaspora status which refers to nonresident of Indonesian citizen who live or work overseas. Rather than having beneficial implications in practice, this inconsistent categorisation will lead to another difficulty in identifying who are parts of the Indonesian diaspora in legal terms and their intended rights and obligations.

\section{Conclusion}

Changes in the demographics of Indonesia have fundamentally influenced the country's human mobility both at national and international levels, especially during the last few decades. After the first congress on the Indonesian diaspora held in Los Angeles in 2012, there has been a growing interest in the Indonesian diaspora.

One of the strong demands of the Indonesian diaspora is having full dual nationality. Although Act No. 12 of 2006 allows the implementation of limited dual nationality, it seems that the government will not agree easily on the idea of full dual nationality. Currently, in response the government has already issued PR No. 76 of 2017. However, from a legal point of view, this new regulation fails to provide adequate instruments for the diaspora. With regard to the importance of finding an appropriate model for the Indonesian diaspora, there is an urgent need to draw comparisons with other countries.

The Indian and South Korean experimentation with diaspora arrangements reflects the politically sensitive character of citizenship. The failure of the adoption of full dual citizenship in India is an important lesson for Indonesia which also sees citizenship as an ideologically sensitive concept. Although a proposal for dual citizenship in South Korea has never surfaced, the effort to develop a diaspora legal regime through immigration schemes also reflects that dual citizenship is not possible in South Korea because it would trigger conflict with other countries, 
especially China. For Indonesia, other schemes beyond dual citizenship should be developed as early as possible, given the current political tendency to seemingly be unable to accept fundamental change in citizenship legal policy. It is important to start discussing the legal categorisation of the Indonesian diaspora and the threshold rights that are needed by diaspora community and will realistically be accepted by the government and legislature.

\section{References}

Basnur, A. (2017). Pemberdayaan masyarakat Indonesia di luar negeri untuk kepentingan nasional [The empowerment of overseas Indonesian society for national interest]. Retrieved from https://www.kemlu.go.id/id/lembar-informasi/Documents/ Paparan\%20 Direktur \%20Diplik\%20\%20Forum\%20Bakohumas\%20Tematik\%20Kemlu\%202017.pdf. (14.03.2018). (In Bahasa Indonesia).

Baubock, R. (2007). "Stakeholder citizenship and transnational political participation: A normative evaluation of external voting", Fordham Law Review, 75(5): 2396-2447.

Budiari, I. (2017, August 19). “Diaspora to get state recognition from new card", The Jakarta Post.

Brubaker, R. (2005). “The 'diaspora' diaspora”, Ethnic and Racial Studies, 28(1): 1-19.

Dewansyah, B (2016). "Indonesian diaspora movement and citizenship law reform: Towards 'semi dual citizenship' for overseas Indonesian descendants". Paper presented at The Asian Law \& Society Association (ALSA) Inaugural Conference, Faculty of Law National University of Singapore, September 22-23, 2016. (unpublished paper).

Dubey, M. (2013). "Changing salience of the relationship between the Indian diaspora and India", Diaspora Studies, 1(3): 73-84.

Ember, M., Ember, C., Skoggard, I. (Eds). (2005). Encyclopedia of Diasporas, Immigrant and Refugee Cultures Around The World, New York: Springer.

Hassall, G. (1999). "Citizenship in the Asia-Pacific: A survey of contemporary issues". In A. Davidson and K. Weekle (eds). Globalization and Citizenship in the Asia-Pacific. London, New York: Macmillan Press Ltd \& St. Martin's Press Inc.

Harijanti., S.D. (2016). "Dwi Kewarganegaraan dan Politik Hukum Kewarganegaraan Indonesia" [Dual Citizenship and Indonesia Legal Policy on Citizenship]. Paper presented at the Workshop on "Dual Citizenship and Urgency of Amendment of Law Number 12/2006 on Citizenship" held by Badan Keahlian DPR RI (Expert Council of Indonesian House of Representatives), Jakarta, September 1, 2016. (in Bahasa Indonesia). (unpublished paper).

Harijanti., S.D. (2017). Report on Citizenship Law: Indonesia. Country Report 2017/04.

Kumar, P. (2015). "Introduction: Socio religious and cultural world of the Indian diaspora”. In P. Kumar (ed). Indian Diaspora: Socio-Cultural and Religious World. Leiden: Brill.

Lee, C. (2012a). "How can you say you're Korean? Law, governmentality and national membership in South Korea", Citizenship Studies, 16(1), 85-102.

Lee, C. (2012b). "The transnationalization of national membership in the era of globalization: Ethnizenship and beyond". The Garvey Schubert Barer Public Lecture at University of Washington School of Law, Seattle, January 30.

Lee, C. (2003). '“Us' and 'them' in Korean law: The creation, accommodation and exclusion of outsiders in South Korea". In A. Rosett, L. Cheng and M. Y.K.Woo (eds). East Asian Law- Universal Norms And Local Cultures. London: Routledge Curzon.

Lee, C. (2017). Interview by second and fourth authors, tape recording, Yonsei University, Seoul - South Korea, May 10, 2017.

Muhidin, S., and Utomo, A., (2015). "Global Indonesian diaspora: How many are there and where are they?", Journal of ASEAN Studies, 3(2): 93-101.

Naujoks, D. (2015). "The securitization of dual citizenship. National security concerns and the making of the overseas citizenship of India", Diaspora Studies, 8(1): 18-36.

Sahai, P. S. (2013). "India's engagement with diaspora: Government communication, platform, and structure", Diaspora Studies, 6(1): 50-60. 


\section{Citizenship and the Indonesian Diaspora}

Santoso, M. I. (2014). Diaspora, Globalisme, Keamanan dan Keimigrasian [Diaspora, Globalism, Security and Immigration]. Bandung: Pustaka Reka Cipta. (in Bahasa Indonesia).

Tan, E., Cullamar, P., (1993). "The Indonesian diaspora and Philippine-Indonesian relations", First Quarter, 41(1): 38-50.

World Bank Group (2016). Migration and Remittances Fact-book 2016. Retrieved from https://siteresources.worldbank.org/INTPROSPECTS/Resources/334934-1199807908806/ 4549025-1450455807487/Factbookpart1.pdf.Accessed: 14.03.2018.

Xavier, C. (2011). "Experimenting with diasporic incorporation: The overseas citizenship of India", Nationalism and Ethnic Politics, 17(1): 34-53.

Yoon, I. (2007a). "A comparison of the South and North Korean policy of overseas Koreans", in "Korean diaspora and strategies of global networking", Korean and Korean American Studies Bulletin, 16(1): 80-99.

Yoon, I. (2007b). "Introduction", in "Korean diaspora and strategies of global networking", Korean and Korean American Studies Bulletin, 16 (1): vii-x. 